\title{
Effect of SXWS/WSXWS peptides on chemotaxis and adhesion of the macrophage-like cell line J774
}

\author{
Rita Szabó ${ }^{a}$, Orsolya Láng ${ }^{b}$, Júlia Láng ${ }^{b}$, Eszter Illyés ${ }^{a}$, László Köhidai $^{b^{*}}$, Ferenc Hudecz $^{a, c^{*}}$ \\ ${ }^{\mathrm{a}}$ Research Group of Peptide Chemistry, Hungarian Academy of Sciences, Budapest, 112, \\ P.O. Box 32, H-1518, Hungary, \\ ${ }^{\mathrm{b}}$ Department of Genetics, Cell- and Immunobiology, Semmelweis University, Nagyvárad tér \\ 4, Budapest 1089, Hungary \\ ${ }^{\mathrm{c}}$ Department of Organic Chemistry, Eötvös Loránd University, Budapest, 112, P.O. Box 32, \\ H-1518, Hungary \\ *authors contributed equally to this study.
}

\begin{abstract}
WSXWS motif is a conserved amino acid sequence which is present in type I cytokine receptors. This motif that can be found both in the ligand binding chains and signal transducer molecule of the receptors with different amino acids at the position ' $\mathrm{X}$ ', plays a role in the receptor folding, ligand binding and signal transduction as well. Structural analysis proved that WSEWS motif of IL-6R is located in a highly accessible location in the protein. Structural properties and chemotaxis of a tetrapeptide library with SXWS sequence, where X was the 19 proteinogenic amino acids except cystein were systematically studied earlier. It has been proved that $C$-terminal amidation and the identity of amino acid ' $X$ ' had a pronounced influence on the chemotactic properties, but less of the structure of the peptides. Here we present our findings on the effect of a tetra- and a pentapeptide library with the sequence of SXWS and WSXWS on the chemotaxis and adhesion of J774 murine macrophage cell line. We studied the effect of the presence/absence of $N$-terminal tryptophan and the different amino acids at the ' $\mathrm{X}$ ' position on these physiological responses. Results indicated that amino acid ' $\mathrm{X}$ ' had a marked influence on chemotaxis, adhesion as well as on proliferation induced by (W)SXWS peptides. Elongation of SXWS sequence with a tryptophan at the $N$ terminus also altered pronouncedly all the physiological responses of the cells studied. A good correlation could be observed between the chemotaxis and the proliferation and physicochemical parameters of the amino acid ' $\mathrm{X}$ '.
\end{abstract}




\section{INTRODUCTION}

The WSXWS pentapeptide motif is a characteristic sequence of cytokine receptor family type I such as IL-2R, IL-4R, IL-6R, IL-7R and interferon receptors (Bazan et al., 1990, Foxwell et al., 1992). This highly conserved sequence has a great significance in the regulation of the immune system, since it is present both in the ligand binding chains of cytokine receptors type I e.g. IL-6R $\alpha$ chain and also in the gp130 protein, the common signal transducer molecule of the IL-6 receptor family such as oncostatin M, leukemia inhibitory factor (LIF) and ciliary neurotrophic factor (CNTf) (Kishimoto et al., 1995). WSXWS motif plays a significant role in the correct folding of the proteins of these receptors (Hilton et al., 1996) as well as it is required for the ligand binding and signal transduction in the same signaling pathway (Yawata et al., 1993; Kishimoto et al., 1995). In case of IL-6R structural analyses proved that WSEWS motif is located on a loop in the hinge region between two barrel-like fibronectin type domains, therefore they are accessible for the ligand (Yawata et al., 1993). A variety of amino acids can occur at the position ' $\mathrm{X}$ '. WSEWS sequence can be found in the IL-6R $\alpha$ chain (Biró et al., 1995), WSDWS motif is present in gp130 molecule (Hilton et al., 1996, Kernebeck et al., 1999), while erythropoetin receptor contains a WSAWS motif (Furmanek et al., 2003). Meissner and coworkers found that WSKWS sequence was essential for the inhibition of cytokine signaling mediated by common $\gamma$ chain of the soluble cytokine receptor in mice (Meissner et al., 2001)

Structural properties of a tetrapeptide library with SXWS sequence, where X position was substituted with all proteinogenic amino acids except cystein were studied earlier (Láng et al., 2012). It has been established that most of the tetrapeptides (except $X=$ Gly, Pro or Arg) have a non-flexible conformation stabilized by a characteristic H-bond pattern, from which the $\mathrm{X}$ residue emerges and has no significant influence on the conformation of the whole peptide. Chemotactic characteristics of synthetic peptides has been investigated on monocyte and lymphocyte cultures (Köhidai et al., 2002) and on the ciliated protozoan Tetrahymena pyriformis as well. Tri-, tetra-, penta- and hexapeptides containing EWS motif and a tetrapeptide library with 19 proteinogenic amino acids at the $\mathrm{X}$ position were also systematically examined. These results showed that some peptides like SEWS (Chemotaxis index $=660 \%$ ) had a pronounced positive chemotactic potential on Tetrahymena pyriformis, whereas shorter (EWS) and elongated (WSEWS) sequences rather elicited a negative chemotactic effect. Amidation of the C-terminus of the peptides and the quality of amino acid at position ' $\mathrm{X}$ ' also greatly influenced the chemotactic properties of the peptides (Köhidai et al., 2003a, Illyés et al., 2002).

Migration of monocytes and macrophages play an important role in the early steps of the immune response. Thus, we wanted to investigate, how a mammalian monocyte derived cell line J774 reacts to the peptides containing SXWS motif. J774 cells have been used for different cell physiological studies, e.g. signal transduction (Kügler et al., 1997), phagocytosis, (Kügler et al., 1997, Ralph and Nakoinz, 1975, Liang-Takasaki et al., 1982) and chemotactic activity (McCloskey et al., 1999, Zhou et al., 2012) have been equally investigated.

In this communication we describe our new findings on the effect of a tetrapeptide (SXWS) and a pentapeptide (WSXWS) library on the chemotaxis and adhesion of J774 murine macrophage cell line. In order to clarify the correlation between the chemical structure (amino acid length, composition and sequence) of the peptides including the role of amino acid X, we studied the chemotaxis and adhesion of $\mathbf{J} 774$ cells elicited by the peptides in several aspects. Our objective was (i) to examine whether the elongation of SXWS peptides with a tryptophan on the $N$ terminus can influence these physiological responses and (ii) to reveal whether 
amino acid substitutions at the $\mathrm{X}$ position are able to alter ability of the peptide to elicit chemotaxis, adhesion and proliferation in $\mathbf{J} 774$ cells.

\title{
MATERIALS AND METHODS
}

\begin{abstract}
Abbreviations
Abbreviations of amino acids and their derivatives follow the revised recommendation of the IUPAC-IUB Committee on Biochemical Nomenclature entitled "Nomenclature and Symbolism for Amino Acids and Peptides" (recommendations of 1983). All amino acids are 1 configuration unless otherwise stated. The other abbreviations in this paper are the following: DMF: $N, N$-dimethylformamide, DCM: dichloromethane, DIC: $N, N^{\prime}$-diisopropylcarbodiimide, DMAP: 4-(dimethylamino)pyridine, HOBt: 1-hydroxybenzotriazole, TFA: trifluoroacetic acid, FBS: fetal bovine serum, DMSO: dimethyl sulfoxide, PBS: phosphate buffered saline, CF: 5(6)-carboxyfluorescein, MTT: 3-(4,5-dimethylthiazol-2-yl)-2,5-diphenyltetrazolium bromide, f-MLF: formyl-methyonyl-leucyl-phenylalanie
\end{abstract}

\section{Materials}

p-Alkoxybenzylalcohol resin (Wang-resin, $0.96 \mathrm{mmol} / \mathrm{g}$ ) was obtained from Bachem, Bubendorf, Switzerland (Cat. No. D 1250; lot 504143). Fmoc-L-amino acids were purchased from Fluka, Buchs, Switzerland. Reagents (DIC, DMAP, HOBt, piperidine, TFA) and solvents (DMF and DCM) were Fluka products of analytical grade.

\section{Peptide synthesis}

Synthesis of the peptides with free C-terminal carboxylic group was performed on Wang resin by manual solid phase synthesis using Fmoc/t Bu strategy with a DIC/HOBt coupling protocol as described before (Illyés et al., 2002). Briefly, the resin $(0.96 \mathrm{mmol} / \mathrm{g})$ was swollen in DMF. Coupling of the Fmoc-protected first amino acid to the resin was performed with DIC using DMAP as an acylating reagent. During the coupling cycles, first the resin was swollen with DMF, Fmoc deprotection was performed with piperidine/DMF (1:1, v/v; for 1, 9 and 1 min) followed by washing with DMF $(5 \times 1 \mathrm{~min}) ; 3$ eq. of Fmoc-amino acids were pre-activated for $5 \mathrm{~min}$ in the presence of HOBt and DIC in DMF and coupled for $90 \mathrm{~min}$. Resin was then washed with DMF $(4 \times 2 \mathrm{~min})$ and DCM $(2 \times 2 \mathrm{~min})$. The efficiency of the coupling was checked with ninhydrin test. Peptides were cleaved from the resin with the mixture of TFA $(95 \%)$, ethanedithiol $(2.5 \%)$ and water $(2.5 \%)$ for $3 \mathrm{~h}$. The mixture was then filtered, the filtrate was precipitated with ether, centrifuged in a sealed tube, then it was washed three times with ether, dissolved in water or $\mathrm{AcOH}$, freeze dried and purified by RP-HPLC. The purity of the peptides was checked with analytical RP-HPLC and mass spectrometry.

\section{Cell culturing}

J774 murine macrophage cell-line was maintained in RPMI 1640 medium containing 10\% FBS, $2 \mathrm{mM}$ L-glutamine, and $0.16 \mathrm{mg} / \mathrm{mL}$ streptomycin at $37^{\circ} \mathrm{C}$ in $5 \% \mathrm{CO}_{2}$ atmosphere. Cells were harvested in logarithmic phase of growth.

\section{Chemotaxis assay on $\mathbf{J 7 7 4}$ cells}


Chemotactic ability of the cells was measured in a 96 well NeuroProbe ${ }^{\circledR}$ chamber. The peptides were dissolved in RPMI-1640 medium and were applied at $10^{-12} \mathrm{M}, 10^{-10} \mathrm{M}, 10^{-8} \mathrm{M}$ and $10^{-6} \mathrm{M}$ concentrations. Complement C5a (McCloskey et al., 1999) was applied as positive control. A polycarbonate filter with $5 \mu \mathrm{m}$ pore diameter was placed between the inner chambers containing the peptide solution and the outer chambers, in which $\mathrm{J} 774$ cells were placed $\left(10^{5}\right.$ cells/well $)$. The chamber was incubated at $37^{\circ} \mathrm{C}$ for $3 \mathrm{~h}$. The amount of the viable cells migrated to the peptide solution was determined by MTT assay. MTT $(0.36 \mathrm{mg} / \mathrm{mL})$ dissolved in 0.1 M PBS (pH 7.4) was added to each well and the inner chamber was incubated with MTT for 24 hours, then crystals were dissolved in DMSO and optical density was detected by ELISA reader (Labsystems Multiskan MS, Finland) at $\lambda=540 \mathrm{~nm}$ and $\lambda=620 \mathrm{~nm}$ as reference wavelength. Statistical analysis of data was performed using Student's $t$ test of Origin 8.6 at the $95 \%$ confidence level.

\section{Measurement of the adhesion and proliferation of $\mathbf{J 7 7 4}$ cells}

Adhesion and proliferation of $\mathrm{J} 774$ cells were monitored in real-time mode in xCELLigence SP system (Roche Applied Science, Indianapolis, USA) by measuring the change of electrical impedance in a microelectrode array containing 96-well E-plate (ACEA Biosciences, Ind., San Diego, USA). At first, impedance of culture medium was recorded as a baseline and absolute control. After 1 hour pre-incubation, $10^{4}$ cells were plated into each well with the solution of the peptides dissolved in culture medium $(\mathrm{c}=100 \mu \mathrm{g} / \mathrm{mL})$. Adhesion and cell proliferation was monitored for 72 hours at $37^{\circ} \mathrm{C}$ in $5 \% \mathrm{CO}_{2}$ atmosphere. Based on the impedance change cell index data were calculated by the RTCA 1.2 software of xCELLigence system by the following formula

Cell Index $=\left(Z_{i}-Z_{0}\right) / 15(1)$

where $\mathrm{Z}_{0}$ is electrical impedance at 0 time point and $\mathrm{Z}_{\mathrm{i}}$ is electrical impedance at $i$ time point.

Each data point represents the average of three identical values of parallel samples. Besides the variation of Cell Index compared to the baseline at different time point (delta Cell Index, $\Delta \mathrm{CI})$, the slope of the curve was also estimated by the RTCA 1.2 software. During the evaluation of results the following parameters were considered following normalization to the average of negative control wells: i. normalized slope of the early part of the impedance curve (about the first $3 \mathrm{~h}$ post seeding) representing the effect of treatment on the early adhesion phase; ii. normalized standard deviation value of parallel measurements at time point that was chosen as end point in slope estimation (range fitting study iii. normalized $\Delta \mathrm{CI}$ at $24 \mathrm{~h}$ of treatment; iv. normalized slope of the impedance curve between $30 \mathrm{~h}$ and $72 \mathrm{~h}$ representing the effect of treatment on the cell proliferation.

\section{RESULTS AND DISCUSSION}

\section{Chemotaxis of $\mathbf{J 7 7 4}$ cells}

Chemotaxis of J774 cells was measured in a 96 well NeuroProbe ${ }^{\circledR}$ chamber at $10^{-12} \mathrm{M}, 10^{-10}$ $\mathrm{M}, 10^{-8} \mathrm{M}$ and $10^{-6} \mathrm{M}$ concentrations at $37^{\circ} \mathrm{C}$ for $3 \mathrm{~h}$ with complement $\mathrm{C} 5 \mathrm{a}$ as positive control (McCloskey et al., 1999). The number of the viable cells migrated was determined by MTT assay. The chemotactic activity of the peptides is summarized in Table 1. SXWS peptides 
(where $\mathrm{X}=\mathrm{A}, \mathrm{F}, \mathrm{G}, \mathrm{M}, \mathrm{S}$ ) could elicited a positive chemotaxis on $\mathrm{J} 774$ cells. SMWS proved to be the most effective chemoattractant at $10^{-6} \mathrm{M}$ (chtx. idx.=250 $\left.555 \%\right)$. SXWS peptides, where $\mathrm{X}=\mathrm{D}, \mathrm{K}, \mathrm{P}, \mathrm{T}, \mathrm{Y}$ induced a negative chemotactic response. In case of some peptides we could observe a diverse effect depending on the peptide concentration. SQWS was chemoattractant at $10^{-10} \mathrm{M}$ and it acted as a chemorepellent at $10^{-6} \mathrm{M}$ concentration. Similarly, SRWS was repellent at $\mathrm{c}=10^{-12} \mathrm{M}$ and it was neutral at $10^{-8} \mathrm{M}$ concentration. We were looking for correlations between chemotactic activity of the peptides and some physicochemical properties of the corresponding ' $X$ ' amino acids (Table 2). We found that in case of peptides with SXWS sequence, a lower hydropathy could be observed for the ' $\mathrm{X}$ ' amino acids in the chemorepellent peptides. In case of WSXWS sequence we found that repellent peptides had a higher average $\mathrm{pK}_{\mathrm{a}}$ of the side chains of ' $\mathrm{X}$ ' amino acids, compared to the neutral peptides. The other difference was, similarly to the SXWS peptides, the lower average hydropathy of the amino acids ' $\mathrm{X}$ ' in the repellent peptides. On the other hand, we observed that if tetrapeptides were elongated with a tryptophan at the $N$ terminus, most of the peptides lost their chemotactic activity, or showed an altered chemotactic effect (Figure 1). According to the different chemotactic response we could distinguish the following five groups: group I. where SXWS was attractant and WSXWS was neutral (X=A, F, G, M, S); group II. SXWS was attractant, WSXWS was repellent $\left(X=Q\right.$ at $\left.c=10^{-10} \mathrm{M}\right)$; group III. SXWS was repellent, WSXWS was neutral ( $\mathrm{X}=\mathrm{D}, \mathrm{K}, \mathrm{Q}$ at $\mathrm{c}=10^{-6} \mathrm{M}, \mathrm{R}$ at $\left.\mathrm{c}=10^{-12} \mathrm{M}, \mathrm{Y}\right)$; group IV. SXWS was neutral, while WSXWS was repellent $\left(X=I, N, R\right.$ at $\left.c=10^{-8} \mathrm{M}, \mathrm{W}\right)$; and group V. SXWS was repellent, WSXWS was attractant $(X=T)$. We could not detect the change of chemotactic potential from neutral to attractant, or did not find any SXWS-WSXWS peptide pairs, where both peptides proved to be chemoattractant. The change of the chemotactic potential of the peptides is showed in Table 3 and Figure 2. We could distinguish two SXWSWSXWS peptide pairs, which influenced the chemotaxis of J774 cells into the same direction $(\mathrm{X}=\mathrm{P}, \mathrm{Y})$. In case of some peptides we could observe a similar effect in $\mathrm{J} 774$ cells compared to Tetrahymena pyriformis: SXWS peptides, where X was A, M, Q and S were attractant, while SKWS, SYWS and WSYWS peptides were repellent in both cells types.

\section{Chemotactic range fitting}

Chemotactic range fitting is a phenomenon which describes the relationship between the chemotactic activity and the range of the effectivity (Köhidai et al., 2003b). According to data of literature chemoattractant ligands can take their effect in a wide concentration range, whereas the concentration range of the effect in case of neutral or chemorepellent ligands is usually narrower. Our results show a good correlation with former observations on Tetrahymena pyriformis (Kőhidai et al., 2003b; Láng et al., 2012). The most effective chemoattractant tetrapeptide (SMWS) elicited an effect in the widest range (100-250\%) and other chemoattractant tetrapeptides such as SQWS (100-141\%), SAWS (59-134\%) and SSWS (96-141\%) elicited an effect also in a relatively wide range. Neutral and repellent SXWS tetrapeptides as well as WSXWS pentapeptides, including the only attractant one (WSTWS) induced an effect in a much narrower range (Figure 3 ).

\section{Adhesion and proliferation}

Adhesion and proliferation of J774 cells were studied in xCELLigence SP system by measuring the change of electrical impedance on fibronectin coated surface of a 96-well Eplate. Cell adhesion was followed for $72 \mathrm{~h}$. Change of relative cell index $(\Delta \mathrm{CI})$ was depicted in the function of time. Curves of two peptide pairs, where $\mathrm{X}=\mathrm{N}$ (SNWS/WSNWS) or $\mathrm{M}$ (SMWS/WSMWS) are shown on Figure 4. Early phase of adhesion was characterized by the normalized slope of the first $2 \mathrm{~h}$ from the addition of the cells; normalized $\Delta \mathrm{CI}$ at $24 \mathrm{~h}$ and normalized slope of treatment between $30 \mathrm{~h}$ and $72 \mathrm{~h}$ was calculated for describing cell 
proliferation.

\section{Early phase of adhesion (2-4 h)}

At the first two hours, six SXWS tetrapeptides (X=G, H, N, P, R and V) as well as three WSXWS pentapeptides ( $X=G, R$ at $c=10^{-12} \mathrm{M}$ and $\mathrm{S}$ ) induced a decreased attachment to the surface compared to the untreated control. A faster adhesion was elicited only by a few WSXWS peptides (X= D, E, L, M), but none of the SXWS tetrapeptides (Figure 5A).

\section{Long term proliferation of J774 cells elicited by (W)SXWS peptides}

According to the slope of the adhesion curves from $3 \mathrm{~h}$ to $72 \mathrm{~h}$, three tetrapeptides $(\mathrm{X}=\mathrm{E}, \mathrm{K}, \mathrm{Q})$ and five pentapeptides $\left(\mathrm{X}=\mathrm{E}, \mathrm{Q}, \mathrm{R}\right.$ at $\mathrm{c}=10^{-12} \mathrm{M}, \mathrm{W}, \mathrm{Y}$ ) proved to proliferative to $\mathrm{J} 774$ cells (10-20\%). A slight inhibitory effect compared to the control could be observed in case of four SXWS tetrapeptides (X=F, L, M. V). No WSXWS pentapeptides inhibited the long term proliferation of $\mathrm{J} 774$ cells (Figure 5B). When analyzing $\Delta \mathrm{CI}$ at $24 \mathrm{~h}$ we found slight differences between the effect of the tetra- and pentapeptides (when $X=F, G, H, I, R, S, V$, $\mathrm{W}, \mathrm{Y}$ ), but in all cases cell indexes of WSXWS peptides were higher than that of SXWS peptides (Figure 6A). When comparing solvent exposed area (SEA) of amino acids at the $\mathrm{X}$ position in the effective and ineffective WSXWS peptides we can observe that in most cases SEA is inversely proportional to the efficacy of proliferation (Figure 6B). Calculating the average of SEA of ' $X$ ' amino acids the effective and ineffective WSXWS pentapeptides, we can see a similar phenomenon: the average SEA of amino acid ' $\mathrm{X}$ ' in case of the effective pentapeptides is relatively low $(2.18=68 \%)$ compared to the average of SEA of the 19 proteinogenic amino acids except cystein $(3.21=100 \%)$. By contrast, the average SEA values in case of ineffective peptides are relatively high $(4.95=154 \%)$ compared to the average of the 19 proteinogenic amino acids except cystein (Table 4).

\section{Chemotactic vs. adhesive peptides?}

The dominance of the physiological responses of J774 cells was different for each peptide. Most of the peptides (SXWS, where X = A, D, F, G, K, M, Q, S, T, Y; and WSXWS, where $\mathrm{X}=\mathrm{I}, \mathrm{P}, \mathrm{Q}, \mathrm{T}, \mathrm{W}, \mathrm{Y}$ ) elicited an either positive or negative chemotactic response and did not influence significantly the adhesion of the cells. In case of four WSXWS peptides $(X=D, E$, $\mathrm{L}, \mathrm{M}$ ) enhanced the adhesion proved to be the dominant physiological response. Except some peptides, which did not elicit either chemotaxis or adhesion, we found two tetrapeptides $(\mathrm{X}=$ $P$ and $R$ at $c=10^{-12} \mathrm{M}$ ) and a pentapeptide (WSRWS at $c=10^{-8} \mathrm{M}$ ) that affected similarly chemotaxis and adhesion. These molecules induced a negative chemotaxis and also inhibited the adhesion of J774 cells at 3h. Besides, a group of 7 peptides (SHWS, SNWS, SRWS at c= $10^{-8} \mathrm{M}$, SVWS, WSGWS, WSRWS at $\mathrm{c}=10^{-12} \mathrm{M}$ and WSSWS) proved to be neutral in chemotaxis studies, but inhibited the early adhesion of J774 cells. Adhesive, chemotactic and proliferative effects of the peptides are summarized in Table 5.

\section{CONCLUSION}

Chemotaxis, cellular adhesion and proliferation are essential physiological responses of the cells. Small peptides, like f-MLF often induce a chemotactic response either in the ciliate protozoan Tetrahymena (Köhidai et al., 2003c) or in organisms at the higher rank of phylogeny like monocytes (Gouwy et al., 2009).

Our finding suggest that (W)SXWS peptides had a significant influence on the chemotaxis, adhesion and proliferation of J774 monocyte-macrophage cell line. We found that the identity of amino acid ' $\mathrm{X}$ ' had a marked influence on the effect of the peptides in case of all physiological responses studied. Elongation of SXWS sequence with a tryptophan at the $N$ 
terminus also altered pronouncedly the characteristics of the physiological reactions of the cells. A good correlation was demonstrated between the chemotactic effect and certain physicochemical parameters (e.g. $\mathrm{pK}_{\mathrm{a}}$ of the side chain) of the amino acid ' $\mathrm{X}$ '. Also a correlation was established between low hydropathy index of amino acids and negative chemotaxis of the tetra- as well as pentapeptides. On the other hand, the low SEA values of pentapeptides and its proliferation feature was in harmony.

\section{ACKNOWLEDGEMENTS}

This study was supported by the Hungarian Research Fund (OTKA) K104385. R. Szabó acknowledges the support of the Post-doctoral Program of the Hungarian Academy of Sciences

\section{REFERENCES}

Bazan JF. 1990. Structural design and molecular evolution of a cytokine Receptor Superfamily. Proc. Natl. Acad. Sci. USA 87: 6934-6938.

Biró J, Bősze Sz, Hudecz F, Nagy Z, Rajnavölgyi É, Schmidt B, Rákász É, Falus A. 1995. The effect of WSEWS pentapeptide and WSEWS-specific monoclonal antibodies on constitutive and IL-6 induced acute-phase protein production by a human hepatoma cell line, HEPG-2. Immunol. Lett. 46: $183-187$.

Bordo D, Argos P. 1991. Suggestions for "safe" residue substitutions in site-directed mutagenesis. J. Mol. Biol. 217: 721-729.

Foxwell BM, Barrett K, Feldmann M. 1992. Cytokine receptors: structure and signal transduction. Clin Exp Immunol. 90:161-169.

Furmanek A, Hess D, Rogniaux H, Hofsteenge J. 2003. The WSAWS motif is C-hexosylated in a soluble form of the erythropoietin receptor. Biochemistry 42: 8452-8458. DOI: 10.1021/bi034112p

Gouwy M, Struyf S, Verbeke H, Put W, Proost P, Opdenakker G, Van Damme J. 2009. CC chemokine ligand-2 synergizes with the nonchemokine G protein-coupled receptor ligand fMLP in monocyte chemotaxis, and it cooperates with the TLR ligand LPS via induction of CXCL8. J. Leukoc. Biol. 86: 671-680. DOI: 10.1189/jlb.1008638

Hilton DJ, Watowich SS, Katz L, Lodish HF. 1996. Saturation mutagenesis of the WSXWS motif of the erythropoietin receptor. J Biol Chem. 271:4699-4708. DOI: 10.1074/jbc.271.9.4699

Illyés E, Bősze Sz, Láng O. Sebestyén F, Kőhidai L, Hudecz F. 2002. A new class of chemotactic peptides containing EWS motif: A mini-review. Chim. Oggi, 20: 55-61.

http://jenalib.fli-leibniz.de/IMAGE_AA.html

Kernebeck T, Pflanz S, Müller-Newen G, Kurapkat G, Scheek RM, Dijkstra K, Heinrich PC, Wollmer A, Grzesiek S, Grötzinger J. 1999. The signal transducer gp130: Solution structure of the carboxyterminal domain of the cytokine receptor homology region. Protein Sci. 8: 5-12. DOI: $10.1110 /$ ps.8.1.5

Kishimoto T, Akira S, Narazaki M, Taga T. 1995. Interleukin-6 family of cytokines and gp130. Blood. 86:1243-1254. 
Kőhidai L, Schiess N, Illyés E. Láng O., Sebestyén F., Hudecz F., Szebeni J. 2002. Chemotactic effects of SXWS and WSXWS peptides - Phylogenetical aspects. 5th Internat. Congr. WHMA, Debrecen, Hungary

Kőhidai L, Bősze S, Soós P, Illyés E, Láng O, Mák M, Sebestyén F, Hudecz F. 2003(a) Chemotactic activity of oligopeptides containing an EWS motif on Tetrahymena pyriformis: the effect of amidation of the C-terminal residue. Cell Biochem. Funct. 21: 113-120. DOI: 10.1002/cbf.1005

Köhidai L, Láng O, Csaba G. 2003(b) Chemotactic-range-fitting of amino acids and its correlations to physicochemical parameters in Tetrahymena pyriformis-evolutionary consequences. Cell. Mol. Biol. (Noisy-le-grand). 49: OL487-OL495.

Kőhidai L, Török K, Illyés E, Tamási J, Sebestyén F, Láng O, Csaba G, Hudecz F. 2003(c) Characterization of chemotactic ability of peptides containing $N$-formyl-methionyl residues in Tetrahymena fMLP as a targeting ligand. Cell. Biol. Int. 27: 695-700. DOI:10.1016/S10656995(03)00126-4

Kügler S, Schüller S, Goebel W. 1997. Involvement of MAP-kinases and -phosphatases in uptake and intracellular replication of Lysteria monocytogenes in J774 macrophage cells. FEMS Microbiol. Lett. 157: 131-136.

Kyte J, Doolittle, RF. 1982. A simple method for displaying the hydropathic character of a protein. $J$. Mol. Biol. 157: 105-132.

Láng O, Illyés E, Menyhárd DK, Láng J, Sebestyén F, Hudecz F, Kőhidai L. 2012. Chemotaxis induced by SXWS tetrapeptides in Tetrahymena--overlapping chemotactic effects of SXWS sequences and their identical amino acids. J. Mol. Recognit. 25: 24-31. DOI: 10.1002/jmr.1166

Liang-Takasaki CJ, Mäkelä PH, Leive L. 1982. Phagocytosis of bacteria by macrophages: changing the carbohydrate of lipopolysaccharide alters interaction with complement and macrophages. $J$. Immunol. 128: 1229-1235.

McCloskey MA, Fan Y, Luther S. 1999. Chemotaxis of rat mast cells toward adenine nucleotides. $J$. Immunol. 163: 970-977.

Meissner U, Blum H, Schnare M, Röllinghoff M, Gessner A. 2001. A soluble form of the murine common gamma chain is present at high concentrations in vivo and suppresses cytokine signaling. Blood 97: 183-91. DOI: 10.1182/blood.V97.1.183

Ralph P, Nakoinz I. 1975. Phagocytosis and cytolysis by a macrophage tumour and its cloned cell line. Nature 257: 393-394.

Yawata H, Yasukawa K, Natsuka S, Murakami M, Yamasaki K, Hibi M, Taga T, Kishimoto T. 1993. Structure-function analysis of human IL-6 receptor: dissociation of amino acid residues required for IL-6-binding and for IL-6 signal transduction through gp130. EMBO J. 12:1705-1712.

Zhou JJ, Wang YM, Lee VW, Phoon RK, Zhang GY, Wang Y, Tan TK, Hu M, Wang LD, Saito M, Sawyer A, Harris DC, Alexander SI, Durkan AM. 2012. DEC205-DC targeted DNA vaccines to CX3CR1 and CCL2 are potent and limit macrophage migration. Int. J. Clin. Exp. Med. 5: 24-33. 
TABLES

\begin{tabular}{|c|c|c|c|c|}
\hline \multirow{2}{*}{$\begin{array}{c}\text { Peptide } \\
\text { sequence }\end{array}$} & \multicolumn{4}{|c|}{ Chemotaxis index [\% of control] $\pm \mathrm{SD}$} \\
\hline & $10^{-12} \mathrm{M}$ & $10^{-10} \mathrm{M}$ & $10^{-8} \mathrm{M}$ & $10^{-6} M$ \\
\hline SAWS & $87 \pm 35$ & $90 \pm 50$ & $129 \pm 28$ & $134 \pm 17^{*}$ \\
\hline SDWS & $128 \pm 37$ & $77 \pm 19$ & $57 \pm 11^{*}$ & $61 \pm 23 *$ \\
\hline SEWS & $96 \pm 1$ & $98 \pm 7$ & $94 \pm 4$ & $93 \pm 3$ \\
\hline SFWS & $113 \pm 13$ & $108 \pm 8$ & $113 \pm 3 *$ & $99 \pm 6$ \\
\hline SGWS & $98 \pm 9$ & $102 \pm 8$ & $102 \pm 6$ & $125 \pm 7 *$ \\
\hline SHWS & $102 \pm 6$ & $104 \pm 3$ & $106 \pm 8$ & $109 \pm 5$ \\
\hline SIWS & $102 \pm 4$ & $102 \pm 11$ & $99 \pm 6$ & $102 \pm 5$ \\
\hline SKWS & $91 \pm 15$ & $84 \pm 12 *$ & $90 \pm 15$ & $96 \pm 15$ \\
\hline SLWS & $91 \pm 3$ & $88 \pm 10$ & $97 \pm 4$ & $94 \pm 3$ \\
\hline SMWS & $125 \pm 46$ & $107 \pm 30$ & $130 \pm 48$ & $250 \pm 55^{*}$ \\
\hline SNWS & $100 \pm 8$ & $106 \pm 5$ & $100 \pm 8$ & $102 \pm 9$ \\
\hline SPWS & $93 \pm 11$ & $85 \pm 14$ & $85 \pm 9 *$ & $80 \pm 12 *$ \\
\hline SQWS & $101 \pm 28$ & $142 \pm 29 *$ & $94 \pm 36$ & $75 \pm 7 *$ \\
\hline SRWS & $85 \pm 8 *$ & $92 \pm 7$ & $94 \pm 8$ & $91 \pm 7$ \\
\hline SSWS & $96 \pm 10$ & $98 \pm 22$ & $96 \pm 10$ & $141 \pm 14 *$ \\
\hline STWS & $99 \pm 10$ & $95 \pm 5$ & $92 \pm 3$ & $88 \pm 5^{*}$ \\
\hline SVWS & $95 \pm 19$ & $99 \pm 14$ & $100 \pm 17$ & $90 \pm 11$ \\
\hline SWWS & $88 \pm 21$ & $87 \pm 9$ & $102 \pm 12$ & $99 \pm 15$ \\
\hline SYWS & $77 \pm 6^{*}$ & $79 \pm 15 *$ & $85 \pm 7 *$ & $84 \pm 14^{*}$ \\
\hline WSAWS & $98 \pm 3$ & $100 \pm 4$ & $103 \pm 10$ & $109 \pm 11$ \\
\hline WSDWS & $94 \pm 6$ & $98 \pm 4$ & $100 \pm 2$ & $100 \pm 4$ \\
\hline WSEWS & $95 \pm 11$ & $106 \pm 8$ & $109 \pm 9$ & $105 \pm 3$ \\
\hline WSFWS & $100 \pm 12$ & $102 \pm 12$ & $107 \pm 9$ & $100 \pm 8$ \\
\hline WSGWS & $97 \pm 15$ & $111 \pm 6$ & $105 \pm 8$ & $87 \pm 14$ \\
\hline WSHWS & $106 \pm 10$ & $104 \pm 11$ & $104 \pm 12$ & $101 \pm 11$ \\
\hline WSIWS & $88 \pm 3 *$ & $91 \pm 6$ & $92 \pm 6$ & $82 \pm 6^{*}$ \\
\hline WSKWS & $100 \pm 10$ & $104 \pm 10$ & $100 \pm 12$ & $102 \pm 8$ \\
\hline WSLWS & $101 \pm 9$ & $95 \pm 12$ & $100 \pm 11$ & $100 \pm 13$ \\
\hline WSMWS & $92 \pm 4$ & $96 \pm 3$ & $100 \pm 4$ & $106 \pm 8$ \\
\hline WSNWS & $74 \pm 14 *$ & $91 \pm 20$ & $83 \pm 14 *$ & $91 \pm 19$ \\
\hline WSPWS & $86 \pm 14^{*}$ & $87 \pm 11 *$ & $84 \pm 5 *$ & $84 \pm 12 *$ \\
\hline WSQWS & $83 \pm 23$ & $81 \pm 18 *$ & $83 \pm 15 *$ & $91 \pm 14$ \\
\hline WSRWS & $97 \pm 14$ & $87 \pm 15$ & $87 \pm 9 *$ & $97 \pm 9$ \\
\hline WSSWS & $90 \pm 16$ & $106 \pm 11$ & $105 \pm 13$ & $95 \pm 9$ \\
\hline WSTWS & $100 \pm 6$ & $102 \pm 5$ & $104 \pm 8$ & $115 \pm 6^{*}$ \\
\hline WSVWS & $102 \pm 19$ & $105 \pm 16$ & $107 \pm 12$ & $106 \pm 10$ \\
\hline WSWWS & $78 \pm 13 *$ & $87 \pm 12$ & $91 \pm 18$ & $97 \pm 18$ \\
\hline WSYWS & $103 \pm 7$ & $95 \pm 8$ & $84 \pm 6 *$ & $97 \pm 6$ \\
\hline & $10^{-10} \mathrm{M}$ & $10^{-9} M$ & $10^{-8} M$ & $10^{-7} \mathrm{M}$ \\
\hline C5a & $106 \pm 85$ & $102 \pm 10$ & $134 \pm 11 *$ & $149 \pm 11 *$ \\
\hline
\end{tabular}

Table $1 \quad$ Chemotaxis of J774 cells induced by SXWS and WSXWS peptides. Chemotaxis was determined in a 96 well NeuroProbe ${ }^{\circledR}$ chamber at $37^{\circ} \mathrm{C}$ for $3 \mathrm{~h}$. The amount of the migrated cells was determined by MTT assay, chemotaxis index is expressed in the percentage of the negative control. Statistical analysis of data was performed using Student's t test at the $95 \%$ confidence level; *: $p>0.05$ 


\begin{tabular}{|c|c|c|c|c|c|c|c|}
\hline Sequence & $\begin{array}{r}\text { Chemotactic } \\
\text { activity }\end{array}$ & Amino acid $X$ & $\begin{array}{r}\text { average } p K_{a} \\
\left({ }^{\alpha} \mathrm{COOH}\right) \\
\end{array}$ & $\begin{array}{r}\text { average } \mathrm{pK}_{a} \\
\left({ }^{\alpha} \mathrm{NH}_{2}\right) \\
\end{array}$ & $\begin{array}{c}\text { average } p K_{a} \\
\text { (side chain) }\end{array}$ & average $S E A$ & $\begin{array}{r}\text { average } \\
\text { hydropathy }\end{array}$ \\
\hline \multirow[t]{3}{*}{ SXWS } & chemoattractant & A,F,G,M,Q,S & $2.32 \pm 0.15$ & $9.40 \pm 0.34$ & - & $0.56 \pm 0.16$ & $0.3 \pm 2.33$ \\
\hline & neutral & E,H,I,L,N,V,W & $2.17 \pm 0.22$ & $9.44 \pm 0.35$ & $5.09 \pm 1.44$ & $0.59 \pm 0.22$ & $0.20 \pm 3.82$ \\
\hline & chemorepellent & $\mathrm{D}, \mathrm{K}, \mathrm{P}, \mathrm{R}, \mathrm{T}, \mathrm{Y}$ & $2.11 \pm 0.08 *$ & $9.52 \pm 0.69$ & $8.15 \pm 3.73$ & $0.68 \pm 0.16$ & $-2.20 \pm 1.41^{*}$ \\
\hline \multirow[t]{3}{*}{ WSXWS } & chemoattractant & $\begin{array}{ll}\mathrm{T} \\
\end{array}$ & 2.09 & 9.1 & - & 0.71 & -0.7 \\
\hline & neutral & $\mathrm{A}, \mathrm{D}, \mathrm{E}, \mathrm{F}, \mathrm{G}, \mathrm{H}, \mathrm{K}, \mathrm{L}, \mathrm{M}, \mathrm{S}, \mathrm{V}$ & $2.23 \pm 0.20$ & $9.47 \pm 0.33$ & $6.14 \pm 3.10$ & $0.56 \pm 0.19$ & $-0.07 \pm 3.12$ \\
\hline & chemorepellent & $\mathrm{I}, \mathrm{N}, \mathrm{P}, \mathrm{Q}, \mathrm{R}, \mathrm{W}, \mathrm{Y}$ & $2.16 \pm 0.15$ & $9.40 \pm 0.61$ & $11.28 \pm 1.70$ & $0.63 \pm 0.18$ & $-1.54 \pm 2.98$ \\
\hline
\end{tabular}

Table $2 \quad$ Chemotactic activity of the tetra- and pentapeptides and physicochemical properties of the corresponding amino acids at the ' $X$ ' position. Statistical analysis of data was performed using Student's $t$ test; *: $p<0.05$. SEA values for each amino acid were obtained from JENA library of biological macromolecules (Bordo and Argos, 1991). Hydropathy indexes were obtained from Kyte and Doolittle (Kyte and Doolittle, 1982) 


\begin{tabular}{clll}
\hline \multirow{2}{*}{ Amino acid } & \multicolumn{2}{c}{ Chemotactic potential } & $\begin{array}{l}\text { Effective } \\
\text { concentration }\end{array}$ \\
\cline { 2 - 4 } $\boldsymbol{X}$. & \multicolumn{1}{c}{ SXWS } & WSXWS & lg c $[\mathbf{M}]$ \\
\hline $\mathbf{A}$ & chemoattractant & neutral & -6 \\
$\mathbf{D}$ & chemorepellent & neutral & $-8,-6$ \\
$\mathbf{E}$ & neutral & neutral & $-12,-10,-8,-6$ \\
$\mathbf{F}$ & chemoattractant & neutral & -8 \\
$\mathbf{G}$ & chemoattractant & neutral & -6 \\
$\mathbf{H}$ & neutral & neutral & $-12,-10,-8,-6$ \\
$\mathbf{I}$ & neutral & chemorepellent & $-12,-6$ \\
$\mathbf{K}$ & chemorepellent & neutral & -10 \\
$\mathbf{L}$ & neutral & neutral & $-12,-10,-8,-6$ \\
$\mathbf{M}$ & chemoattractant & neutral & -6 \\
$\mathbf{N}$ & neutral & chemorepellent & $-12,-8$ \\
$\mathbf{P}$ & chemorepellent & chemorepellent & $-8,-6$ \\
$\mathbf{Q}$ & chemoattractant & chemorepellent & -10 \\
$\mathbf{Q}$ & chemorepellent & neutral & -6 \\
$\mathbf{R}$ & chemorepellent & neutral & -12 \\
$\mathbf{R}$ & neutral & chemorepellent & -8 \\
$\mathbf{S}$ & chemoattractant & neutral & -6 \\
$\mathbf{T}$ & chemorepellent & chemoattractant & -6 \\
$\mathbf{V}$ & neutral & neutral & $-12,-10,-8,-6$ \\
$\mathbf{W}$ & neutral & chemorepellent & -12 \\
$\mathbf{Y}$ & chemorepellent & neutral & $-12,-10,-6$ \\
$\mathbf{Y}$ & chemorepellent & chemorepellent & -8 \\
\hline Table 3 & Change of the chemotactic potential of SXWS peptides elongated with a tryptophane \\
at the $N$ terminus. Xis any proteinogenic amino acid except cystein.
\end{tabular}




\begin{tabular}{|c|c|c|c|c|}
\hline & $S E A-30 A(\%)$ & Buried (\%) & $S E A-10-30 \AA(\%)$ & SEA of Accessible/Buried \\
\hline $\begin{array}{l}\text { Means of } 19 \text { proteinogenic amino acids except } \\
\text { cystein }\end{array}$ & 64.21 & 23.73 & 12.05 & $\begin{array}{c}76.26 / 23.73=3.21 \\
(100 \%)\end{array}$ \\
\hline $\begin{array}{l}\text { Means of amino acids } \\
\text { F, G, H, I, R, S, V, W, Y } \\
\text { (peaks induced by the corresponding } 9 \text { WSXWS } \\
\text { ligands at } 24 \mathrm{~h} \text { ) }\end{array}$ & 56.44 & 31.44 & 12.11 & $\begin{array}{c}68.55 / 31.44=2.18 \\
(67.91 \%)\end{array}$ \\
\hline $\begin{array}{l}\text { Means of amino acids } \\
\text { A, D, E, K, L, M, N, P, Q, T } \\
\text { (proved to be neutral in the } 10 \text { WSXWS ligands } \\
\text { at } 24 \mathrm{~h} \text { ) }\end{array}$ & 71.2 & 16.8 & 12.00 & $\begin{array}{c}83.2 / 16.8=4.95 \\
(154.20 \%)\end{array}$ \\
\hline
\end{tabular}




\begin{tabular}{ccccccc}
\hline Amino acid & \multicolumn{3}{c}{ SXWS } & \multicolumn{3}{c}{ WS WWS } \\
\cline { 2 - 6 } X & Chemotaxis & Adhesion & Proliferation & Chemotaxis & Adhesion & Proliferation \\
\hline A & + & $\varnothing$ & $\varnothing$ & $\varnothing$ & $\varnothing$ & $\varnothing$ \\
D & - & $\varnothing$ & $\varnothing$ & $\varnothing$ & + & $\varnothing$ \\
E & $\varnothing$ & $\varnothing$ & + & $\varnothing$ & + & + \\
F & + & $\varnothing$ & - & $\varnothing$ & $\varnothing$ & $\varnothing$ \\
G & + & - & $\varnothing$ & $\varnothing$ & - & $\varnothing$ \\
H & $\varnothing$ & - & $\varnothing$ & $\varnothing$ & $\varnothing$ & $\varnothing$ \\
I & $\varnothing$ & $\varnothing$ & $\varnothing$ & - & $\varnothing$ & + \\
K & - & $\varnothing$ & + & $\varnothing$ & $\varnothing$ & $\varnothing$ \\
L & $\varnothing$ & $\varnothing$ & - & $\varnothing$ & + & $\varnothing$ \\
M & + & $\varnothing$ & - & $\varnothing$ & + & $\varnothing$ \\
N & $\varnothing$ & - & $\varnothing$ & $\varnothing$ & $\varnothing$ & $\varnothing$ \\
P & - & - & $\varnothing$ & - & $\varnothing$ & $\varnothing$ \\
Q & + & $\varnothing$ & + & - & $\varnothing$ & + \\
R & $\varnothing$ & - & $\varnothing$ & - & - & $\varnothing$ \\
S & + & $\varnothing$ & $\varnothing$ & $\varnothing$ & - & $\varnothing$ \\
T & - & $\varnothing$ & $\varnothing$ & + & $\varnothing$ & $\varnothing$ \\
V & $\varnothing$ & - & $\varnothing$ & $\varnothing$ & $\varnothing$ & $\varnothing$ \\
W & $\varnothing$ & $\varnothing$ & $\varnothing$ & - & $\varnothing$ & + \\
Y & - & $\varnothing$ & $\varnothing$ & - & $\varnothing$ & + \\
\hline
\end{tabular}

Table 5 Chemotaxis, adhesion and proliferation of $\mathbf{J 7 7 4}$ cells. $+:$ positive effect, -: negative effect, $\varnothing$ : no effect 


$$
\text { lill|linlinilitiili }
$$




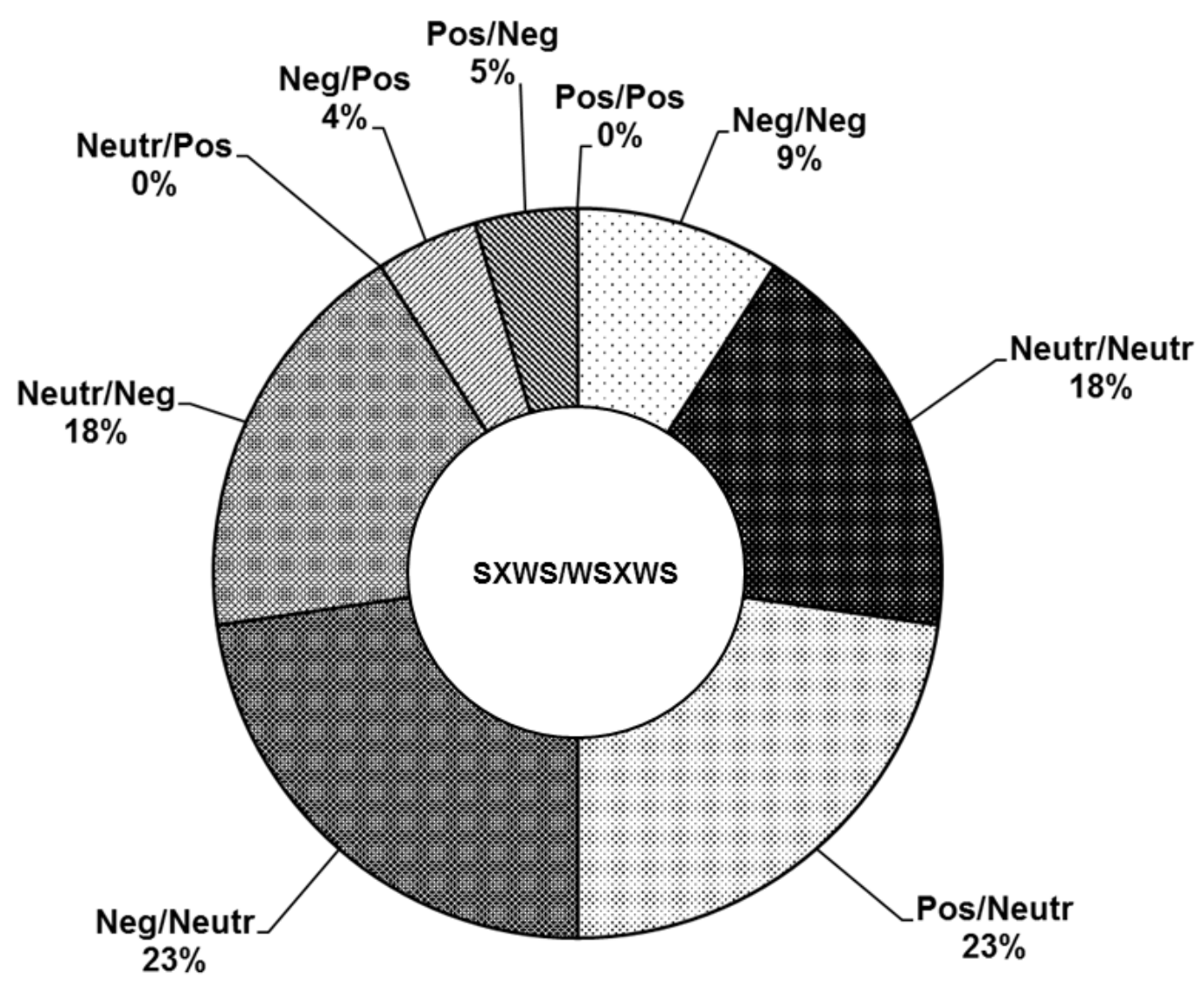

Figure 2 Distribution of the different groups of SXWS/WSXWS peptide pairs according to the change of their chemotactic activity. Pos: both SXWS and WSXWS were attractant, Neg: both SXWS were WSXWS are repellent, Neutr: both SXWS and WSXWS were neutral; Pos/Neutr: SXWS was attractant, WSXWS was neutral, Pos/Neg: SXWS was attractant, WSXWS was repellent, Neg/Neutr: SXWS was repellent, WSXWS was neutral, Neutr/Neg: SXWS was neutral, WSXWS was repellent, Neutr/Pos: SXWS was neutral, WSXWS was attractant, Neg/Pos: SXWS was repellent, WSXWS was attractant.
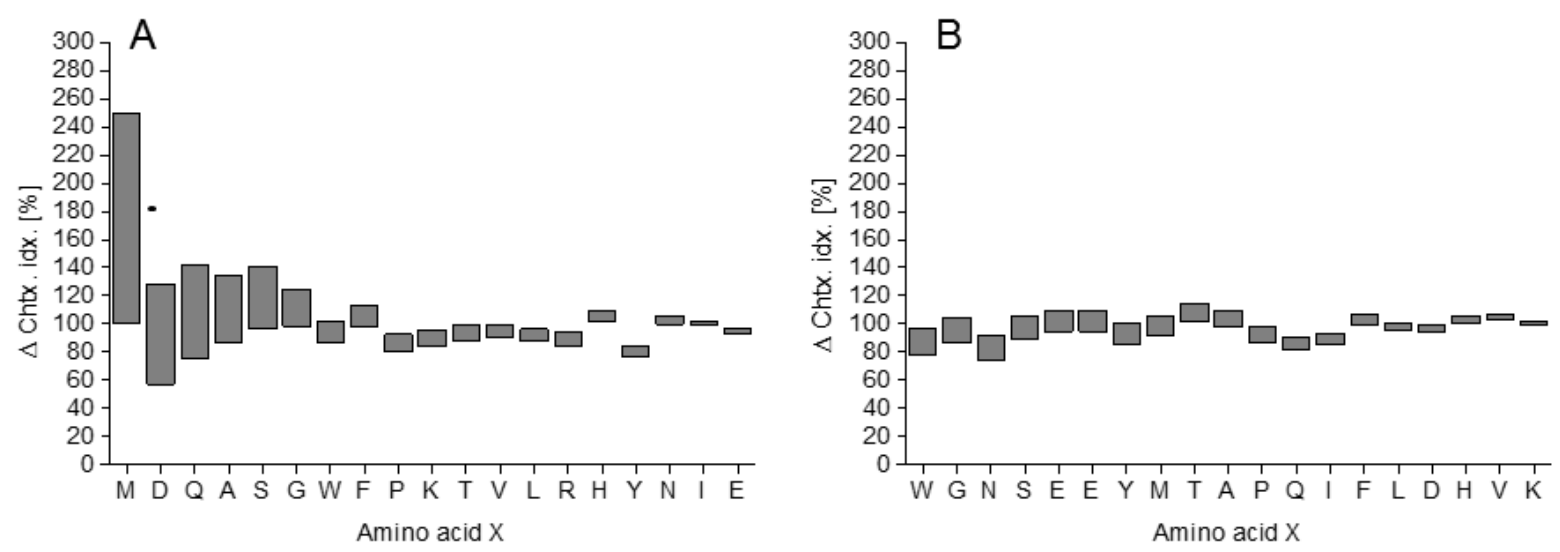

Figure 3 Chemotactic range fitting of SXWS and WSXWS peptides in J774 cells. 

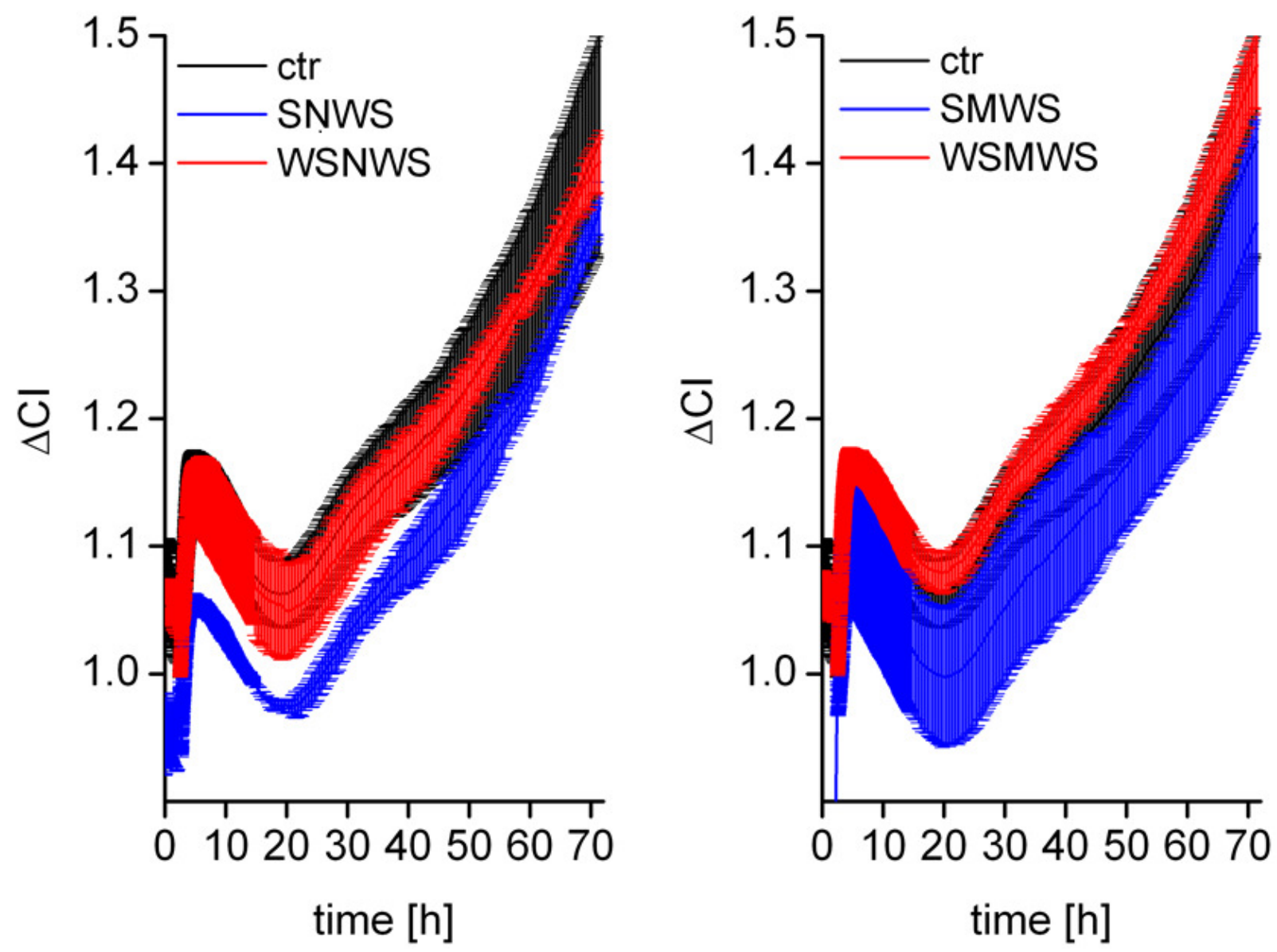

Figure 4 Curves of relative cell index $(\Delta \mathrm{CI}) \pm$ SD of SNWS/WSNWS and SMWS/WSMWS peptide pairs in the function of time. Early adhesion can be characterized by the normalized slope of the first 2 hours from the addition of the cells, while cell proliferation is characterized by normalized $\Delta \mathrm{CI}$ at $24 \mathrm{~h}$ and normalized slope of treatment between $30 \mathrm{~h}$ and $72 \mathrm{~h}$. 

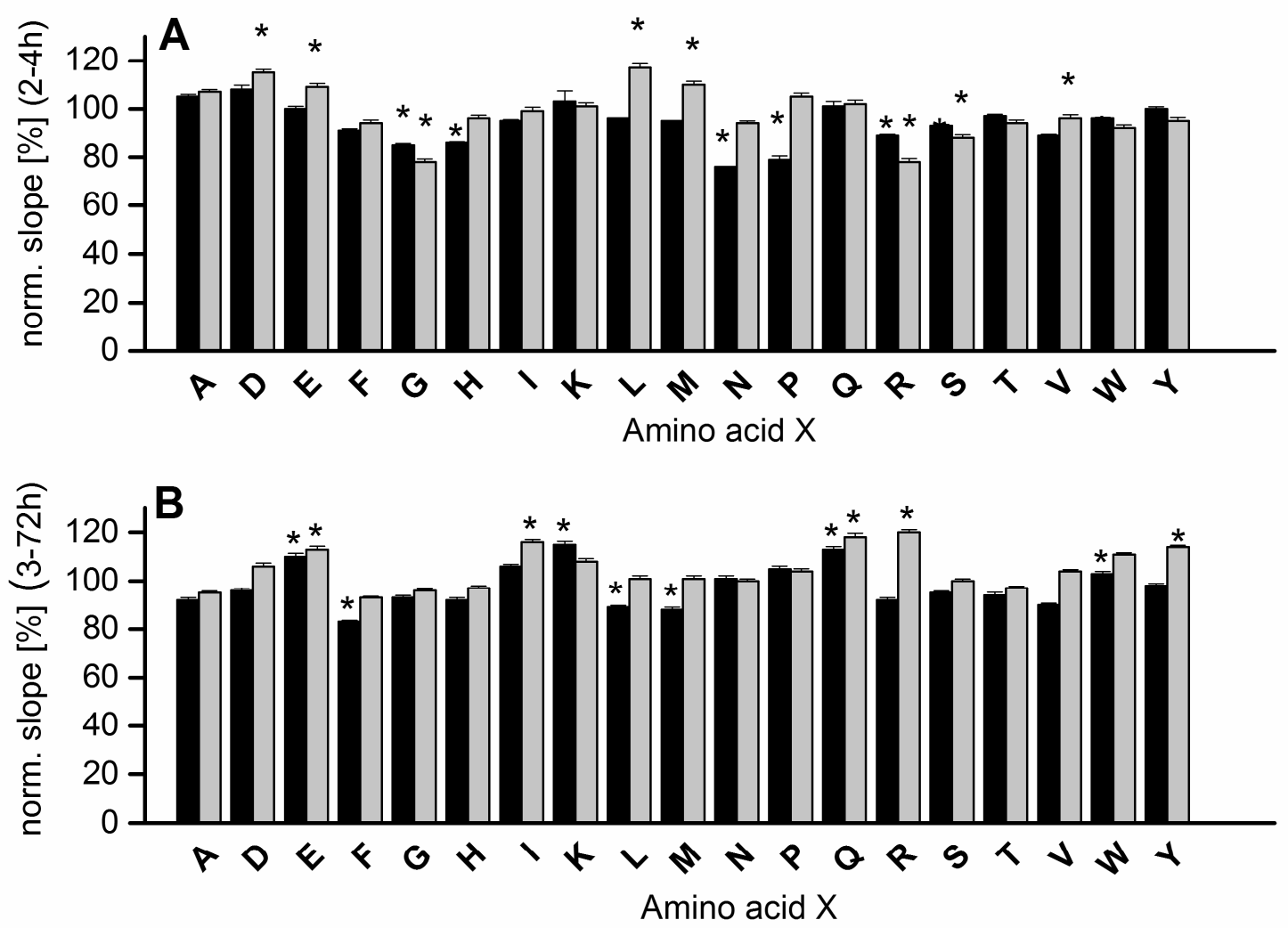

Figure 5 Adhesion (A) and proliferation (B) of J774 cells elicited by SXWS/WSXWS peptides (black/grey columns, respectively). Early adhesion profile of the cells was calculated from the normalized slopes of the curves in the first 2 hours from the addition of the cells. Long term proliferation was calculated from normalized slope of the curves between $30 \mathrm{~h}$ and $72 \mathrm{~h}$. Statistical analysis of data was performed using Student's t test; $*$ : $p<0.05$ 

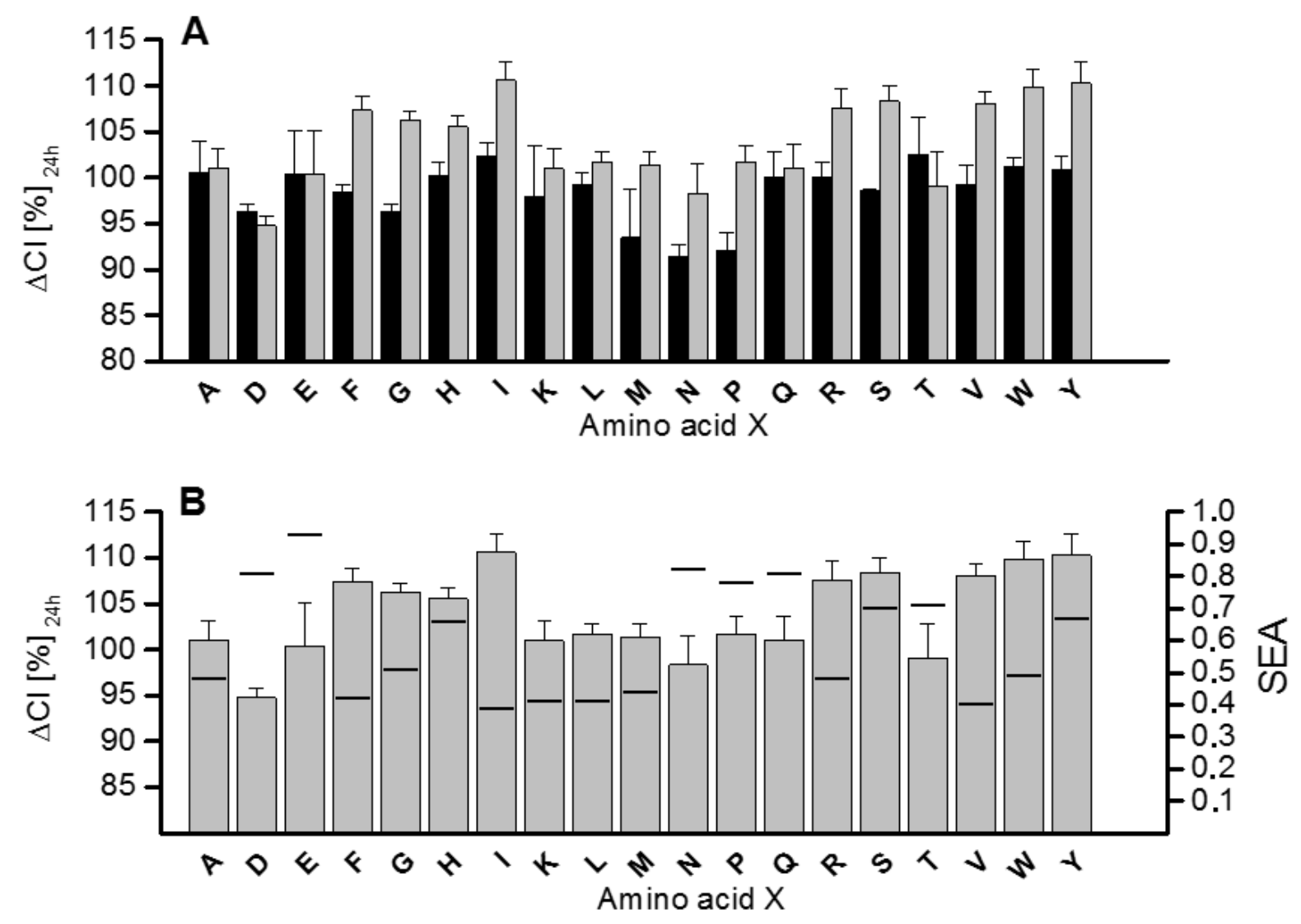

Figure 6 Proliferation of J774 cells 24 hours following the treatment with (W)SXWS peptides (A) Black columns represent SXWS and grey columns represent WSXWS peptides. Correlation between $24 \mathrm{~h}$ proliferation (columns) and solvent exposed area (SEA) (bars) of amino acids at the ' $\mathrm{X}$ ' position (B). Proliferation was characterized by normalized $\Delta \mathrm{CI}$ at $24 \mathrm{~h}$. 